Submitted 09.01.2015. Approved 04.18.2016

Evaluated by double blind review process. Scientific Editors: Glenn Morgan, Marcus Vinícius Peinado Gomes and Paola Perez-Aleman DOI: http://dx.doi.org/10.1590/So034-759020160405

\section{DIFFUSION OF GLOBAL SUSTAINABILITY STANDARDS: THE INSTITUTIONAL FIT OF THE ASC-SHRIMP STANDARD IN INDONESIA}

\author{
Difusão de padrões globais de sustentabilidade: Adequação institucional do \\ padrão ASC-Shrimp na Indonésia \\ Difusión de estándares globales de sostenibilidad: Adecuación institucional \\ del estándar ASC-Shrimp en Indonesia
}

\begin{abstract}
The past two decades saw a rapid proliferation of sustainability standards created by multi-stakeholder partnerships of multinationals and international NGOs. This paper argues that the transformative capacity of these global partnerships to bring about sustainable change largely depends on how well the institutional features of global sustainability standards fit local organizational fields. This paper therefore aims to unravel the dynamics of global-local interactions. To this end, the concept of institutional fit is operationalized to assess whether and how the technical, cultural and political characteristics intrinsic to global sustainability standards are able to connect to local projects, strategies and practices. The introduction of the Aquaculture Stewardship Council's standard into the Indonesian shrimp sector is used as a case to investigate these interactions. This paper shows that a process of fitting occurs when provisional institutions generated within a global partnership can be modified. We argue that global sustainability standards can benefit from steering more explicitly on dovetailing regulative and normative structures of global and local organizational fields. Local NGOs can play important mediating roles in this regard, which can potentially increase the transformative capacity of global standards in terms of generating and accelerating sustainable change.
\end{abstract}

KEYWORDS | Certification, sustainability standards, institutional change, shrimp, Indonesia.

\section{RESUMO}

As duas últimas décadas assistiram a uma rápida proliferação de padrões de sustentabilidade criados por parcerias multi-stakeholder de ONGs multinacionais e internacionais. $O$ presente artigo argumenta que a capacidade transformadora dessas parcerias para trazer mudanças depende, em grande medida, de como as características institucionais dos padrões globais de sustentabilidade se adequam aos campos organizacionais locais. Este artigo, portanto, visa a revelar as dinâmicas das interações globais-locais. Para isso, $o$ conceito de adequação institucional é operacionalizado com o intuito de avaliar se e como as características técnicas, culturais e políticas intrínsecas aos padrões globais de sustentabilidade são capazes de se conectar aos projetos, estratégias e práticas locais. A introdução do padrão do Aquaculture Stewardship Council no setor camaroneiro indonésio é utilizada como caso para a investigação dessas interações. Este artigo mostra que um processo de adequação ocorre quando instituições provisórias geradas no âmbito de uma parceria global podem ser modificadas. Argumentamos que os padrões globais de sustentabilidade podem se beneficiar de uma orientação mais explicitamente voltada ao encaixe entre as estruturas regulatórias $e$ normativas globais e os campos organizacionais locais. As ONGs locais podem desempenhar importantes papéis de mediação nesse sentido, o que pode potencialmente aumentar a capacidade transformadora dos padrões globais em termos de geração e aceleração de mudanças sustentáveis.

PALAVRAS-CHAVE / Certificação, padrões de sustentabilidade, mudanças institucionais, camarão, Indonésia.

\section{RESUMEN}

Las últimas dos décadas vieron una rápida proliferación de estándares de sostenibilidad creados por sociedades de múltiples partes interesadas de ONG multinacionales e internacionales. El presente artículo argumenta que la capacidad transformadora de dichas sociedades globales para causar un cambio sostenible depende en gran medida de lo bien que las características institucionales de los estándares globales se adecuen a los campos organizacionales locales. Por lo tanto, el objetivo de este artículo es descubrir la dinámica de las interacciones globales-locales. A este fin, el concepto de adecuación institucional se pone en práctica para evaluar si y cómo las características técnicas, culturales y políticas intrínsecas de los estándares globales de sostenibilidad son capaces de conectarse con proyectos, estrategias y prácticas locales. La introducción del estándar del Aquaculture Stewardship Council en el sector de camarones de Indonesia se usa como caso para investigar dichas interacciones. El presente artículo muestra que un proceso de adecuación ocurre cuando pueden modificarse instituciones provisorias generadas con una sociedad global. Planteamos que los estándares globales de sostenibilidad pueden beneficiarse de brindar orientación más explícitamente sobre hacer coincidir estructuras reguladoras y normativas de campos organizacionales glo bales y locales. Las ONG locales desempeñan papeles mediadores importantes al respecto, que pueden aumentar potencialmente la capacidad transformadora de estándares globales en términos de generar y acelerar un cambio sostenible.

PALABRAS CLAVE / Certificación, estándares de sostenibilidad, cambio institucional, camarón, Indonesia. 


\section{INTRODUCTION}

The past two decades saw a rapid proliferation of voluntary, private sustainability standards that aim to steer global value chains into a more sustainable direction. Many of these novel transnational governance arrangements are created by multistakeholder partnerships of multinational firms and salient international NGOs (Schouten, Vellema, \& Wijk, 2014). Examples are the Forest, Marine and Aquaculture Stewardship Councils, in which environmental NGOs, in particular the World Wildlife Fund (WWF), teamed up with major multinational firms concerned with ensuring a sustainable supply base in environmentally vulnerable areas (Gereffi, 2013). Such voluntary sustainability standards negotiated in global partnerships are expected to contribute to a transformation in specific producer regions.

The transformative capacity of sustainability standards is, however, far from self-evident. The involvement of large groups of smallholder suppliers in global sourcing, for example, makes addressing these challenges tenacious and complex (Bitzer, Francken, \& Glasbergen, 2008). Many authors point to the limitations and weaknesses of sustainability standards in addressing complex sustainability challenges and promoting systemic change (e.g. Djama, Fouilleux, \& Vagneron, 2011; Ponte, Gibbon, \& Vestergaard, 2011). Bartley (2010) shows in an analysis of forest certification in Indonesia that the changes required to be certified are essentially procedural rather than substantive. Also, there is an increasing concern that global standards are geared towards Northern priorities and fail to substantially include Southern interests and perspectives (Otieno \& Knorringa, 2012; Schouten \& Bitzer, 2015). Moreover, private standards are mainly active in a selected number of (developed) countries (Marx, Maertens, Swinnen, \& Wouters , 2012); by only certifying these low-hanging fruits - those companies or preferred suppliers doing relatively well in terms of sustainability - their transformative capacity is limited and implementation becomes rather symbolic (Bromley, Hwang, \& Powell, 2012).

Standard-setting and the accompanying management models, including auditing and certification procedures, aim at inducing technical and organizational practices that generate socially and environmentally desirable outcomes. However, this instrumental view may lack the required sophistication and flexibility to address the societal challenges motivating the development of sustainability standards. Domestic structures and power configurations are known to disturb, enable or alter the implementation of standards in particular places (Bartley, 2010; Ponte, 2008). Bush and Oosterveer (2015) raise the question whether standard-setting by global coalitions of lead firms and NGOs has enough flexibility to respond to locally embedded solution pathways and external pressures. The rigidity of global sustainability standards might decouple the globally defined plans, rules and intentions from local practices and desirable outcomes (Bromley \& Powell, 2012; Bromley et al., 2012).

We therefore consider a global sustainability standard's transformative capacity dependent on the nature of its interaction with locally embedded practices, rules and institutions. In order to explore this interest further, we use insights from institutional theorization in the management and organization literature (Ansari, Fiss, \& Zajac, 2010; Bromley et al., 2012; Lawrence, Hardy, \& Phillips, 2002; Zietsma \& Mcknight, 2009) to develop and apply a conceptual framework to assess the degree to which global standards are able to blend with ongoing local processes of institutional change. The concept of institutional fit is operationalized to analyses how the technical, cultural and political characteristics intrinsic to global sustainability standards are able to connect to local realities in order to bring about the envisioned change. This entails unpacking transboundary processes and revealing the extent to which standards are flexible and responsive enough to bridge the institutional distance between local institutions and international market institutions (Rivera-Santos, Rufin, \& Kolk, 2012).

The initial phase of the introduction of the global standard Aquaculture Stewardship Council (ASC) into the Indonesian shrimp sector and mangrove forests is used as a case to investigate the global-local interactions resulting from a sustainability standard's introduction. The ASC standard for farmed shrimp is a sustainability standard designed over a number of years in a multistakeholder partnership in which WWF, IDH (Dutch Sustainable Trade Initiative), and European retailers and processors played a key role. Field research in 2011 and 2014 was conducted to answer the question whether and how the features of ASC enable or constrain the capacity to transform practices in the Indonesian shrimp industry, particularly those impacting on mangrove forests, local communities and labor conditions.

This paper is organized as follows. The next section develops our conceptual framework for investigating the nature and extent of institutional fit between a global standard and diverse local realities. Thereafter we explain our research approach and data collection methods. Next, the case study of the diffusion of the ASC-standard into the Indonesian shrimp sector and mangrove forests is presented, which describes the characteristics of the ASC-standard as rule creator, identifies degrees of technical, cultural and political fit, and explores the emerging processes of fitting of the global standard with local contexts. The conclusion reflects on the value of the institutional lens developed in this paper and provides recommendations for further research. 


\section{CONCEPTUALIZING THE DIFFUSION OF GLOBAL SUSTAINABILITY STANDARDS INTO LOCAL PRODUCTION ENVIRONMENTS}

The importance of unpacking the relationship between globally defined sustainability standards and local practices and networks has recently received scholarly attention. Earlier analyses of the structures of global value chains concentrated on governance and distributional aspects, with a leading role for international firms and their network relations with civil society at the consumer end of the value chain. This perspective is considered inadequate for understanding the capacity of global modes of sustainability mechanisms, such as standards, to prompt a transformation process under diverse social and environmental conditions (Bush, Oosterveer, Bailey, \& Mol, 2015). Boström, Jönsson, Lockie, and Mol (2015) emphasize coalition and institution building as conditions for linking border-crossing governance arrangements to local social and environmental change processes. Similarly, Manning, Boons, Hagen, and Reinecke (2012) shift attention from global actors and structures to local conditions for analyzing the variation and co-evolution of sustainability standards. Accordingly, this paper builds on research in the field of global value chains emphasizing embedding in local business systems and economies (Helmsing \& Vellema, 2011; Kusumawati, Bush, \& Visser, 2013; McCarthy, Gillespie, \& Zen, 2012), co-creating sustainability strategies by global standards and the national public domain (Vellema, Ton, Roo, \& Wijk, 2013; Vellema \& Wijk, 2015), privatepublic negotiations around conservation and management of marine resources in specific natural habitats (Adolf, Bush, \& Vellema, in press; Foley, 2013; Foley \& Hébert, 2013; Foley \& McCay, 2014), initiatives remaking relationships between, on the one hand, territorially embedded interests, institutions and discourses of producers, firms and state actors, and on the other, transnational modes of governance such as standards (Foley \& Havice, 2016), and the (in)ability of local and small-scale actors to engage in processes of negotiating to adapt expert-driven management practices (Ponte \& Cheyns, 2013).

A voluntary sustainability standard is a package of predefined rules, prescribed practices, auditing and certification procedures, and preferred management models. This set of practices, rules and techniques is an institution that defines the rules of the game, conveys desired organizational behavior (Wijen, 2014) and, from a sustainability perspective, is expected to be transformative. In contrast to the scholarship on certification looking for material, social and spatial effects of certification, Havice and Iles (2015) analyzed in detail the assemblage of rule- making in multi-stakeholder settings in the aquaculture sector, in particular those initiated by WWF. Their analysis reveals the on-going negotiation processes at different sites explaining the unstable, changeable and contested underpinnings of sustainability standards. Nevertheless, the rule-making processes result in more or less rigid institutions entering production areas. Our interest is to unpack these processes of diffusion, which we consider to be an intermediate process between rule-making and the ultimate effects of standards (Ton, Vellema, \& Ge, 2014). In this interface, the potential transformative capacity of standards is largely generated, which is understood here as the ability to bring about substantial sustainable system changes at production level in a developing context (Glasbergen \& Schouten, 2015).

To assess the (potential) transformative capacity of sustainability standards, we turn to the literature on institutional diffusion that theorizes on the processes through which new organizational practices are adopted. Institutional contexts influence what practices are considered legitimate, and if and how these are adopted (Bromley et al., 2012). New rules and practices may diffuse under the same heading, but attain diverse meanings when adopted in different organizational and institutional contexts (Boxenbaum \& Pederson, 2009; Bromley et al., 2012). These new practices therefore are expected to be modified as processes of blending with local practices take place (Vellema \& Wijk, 2015). Global standard-setting partnerships comprise new institutions constructed in global multi-stakeholder partnerships, which 'touch down' in supplier regions where local institutional arrangements already exist. These so-called 'protoinstitutions' are designed within the boundaries of a partnership or collaboration and need to transcend these boundaries to enable their adoption by other organizations in the institutional field (Marti \& Mair, 2009). Proto-institutions may become fullfledged institutions if they diffuse widely and become adopted (Lawrence et al., 2002, p. 283; Zietsma \& McKnight, 2009, p. 148). The institutional perspective adopted in this paper builds on the theoretical idea that successful diffusion requires institutional translation (cf. Bartley, 2010). Institutions emerging within global partnerships are not automatically adopted in specific localities; when adoption of these institutions occurs, it is through iterative phases of conflict and cooperation (Zietsma \& McKnight, 2009).

Ansari et al. (2010, p. 67) suggest that adoption may vary across organizations because these organizations adapt the new practices through custom adaptation, domestication and reconfiguration to make the new organizational practice fit the organization. The concept of fit is therefore crucial to understand processes of diffusion. To analyze institutional fit, characteristics need to be considered both on the side of the rule creators in this case the standard setting organization and its diffusing 
practices - as well as on the side of the rule receivers - those who are supposed to adopt the sustainability standard, such as businesses, producers, NGOs and government in local production regions.

The framework used in this study first identifies the characteristics of the rule creator, then assesses the degrees of fit with the local context, and finally identifies signals of processes of fitting. In line with Ansari et al. (2010, p. 83), this paper explicitly makes technical, cultural and political characteristics of the rule creator part of the equation. These characteristics of the rule creator form the entry point for analyzing the related types of fit. Technical (and managerial) fit indicates the compatibility of characteristics of existing and new (technical) practices and the way problems are solved and managed, which is influenced by the availability of knowledge about the new practice and the way experts influence problem-solving. Cultural fit indicates the compatibility of the new practice with existing ways to collaborate, to form groups, and to handle tensions and resolve potential conflicts. Political fit indicates the compatibility of the implicit or explicit normative characteristics of the new practice with the interests and agendas of potential adopters. This specifically relates to how enforcement of compliance and compromise, as proto-institutions linked to the standard, may affect the balance of power and interests in adopting organizations (Ansari et al., 2010)

The process of diffusion involves the interaction of the characteristics of proto-institutions with the characteristics of potential adopters. This implies that fit is not a static concept, but the dynamic process of fitting can be considered a prerequisite of the process of diffusion. We hypothesize that the start of interaction between proto-institutions and the organizational field in which it lands sets in motion a process of fitting. If the gap between existing and new practices is too wide to be bridged by changes on either side, friction occurs in which there is neither adoption nor adaption, but rather a process of contestation and protest is set in motion. The willingness or openness to change on both sides - the creator of the new practice and the user of the existing practice - can be used as indicator for the likelihood that the institutional distance can be narrowed or even bridged.

\section{METHODS}

We have chosen a case study to contribute to theory development on institutional change by describing the intrinsic characteristics of the rules and practices of the ASC standard and assessing the consequential diffusion into a specific context. We selected the value chain of farmed shrimp that connects Europe as a major shrimp market with Indonesia, the world's second largest shrimp producer after China (Anderson, 2015). The Indonesian context of shrimp farming discloses that many firm and non-firm actors work on sustainability in the production areas and mangrove forests, that the global ASC standard is being challenged by a variety of local networks, and that the sustainability problem is not confined to intensive shrimp farming practices.

Indonesian shrimp industry actors were, to some extent, involved in the design of the ASC standard. Like the stakeholders of farmed shrimp from other producing countries, they were invited to the six Aquacultural Dialogues on shrimp that were organized by WWF from 2007 to 2010. The last Dialogue was organized in Indonesia (Shrimp Aquaculture Dialogue 2010). Our interviews, however, revealed that European NGOs and private sector representatives, as well as Indonesian NGOs had actively participated in the multi-stakeholder dialogues, whereas the Indonesian private sector had not.

The case study is based on multiple data sources to ensure data triangulation: documents, observations and in-depth interviews. Two criteria were used to select data. First, the data should give an insight in the experiences and views of Indonesian shrimp industry stakeholders regarding the ASC standard, and help identify indications of processes of fitting. Second, the data should be relevant to one of the three thematic issues addressed by the ASC shrimp standard: mangrove forest protection; care for communities surrounding shrimp ponds; or shrimp farm labor. Data were collected in two phases, in 2011 and 2014, which adds a longitudinal dimension to the case study. Documents were sourced from the Indonesian shrimp industry, governmental authorities, NGO's, and the rule creators of the ASC standard. They comprised a range of key (policy) documents that characterized the technical, cultural and political characteristics of either the Indonesian shrimp industry, or the ASC shrimp standard and global sustainability standards in general. Observations were made during one of the ASC's regional multi-stakeholder meetings, in Bali in November 2011.

We further conducted 54 interviews with purposefully selected key informants from 36 organizations along the Indonesian-European value chain of shrimp. Seven out of the 36 key organizations were interviewed twice to investigate progress during the intermediate period. In the Netherlands, the interviewees comprised representatives of a major retailer and a shrimp processor-importer, both of whom source farmed shrimp from Indonesia, as well as the lead officers from the ASC standard organization and the Dutch Sustainable Trade Initiative (IDH). The far majority of interviews were carried out in Indonesia, basically in two local contexts of West-Java and South Sumatra (Lampung), the two main shrimp producing regions (Dujin, Beukers, \& Pijl, 2012). The interviewed organizations comprised 
seven Indonesian shrimp processing-exporting firms and their marketing organization; eleven social and environmental NGOs that are either Indonesian branches of international NGOs or independent domestic organizations; seven aquaculture, forestry and environmental protection departments of Indonesian Ministries and their provincial counterparts in West-Java and Lampung; two semi-extensive shrimp farms; a private village mangrove nursery near Lampung; and five aquaculture and forestry specialists from Indonesian universities. All interviews were extensively summarized in digital files, sent back to interviewees for feedback and later coded with ATLAS TI during the analysis process.

\section{CASE STUDY: THE DIFFUSION OF THE ASC STANDARD INTO THE INDONESIAN SHRIMP SECTOR}

\section{The origins and characteristics of the ASC Shrimp standard}

Shrimp is an important Indonesian export product, which is sold at markets in the USA (40\%), Japan (35\%) and the EU (15\%). The far majority (70\%) of the exported shrimp is being produced in intensive or fully integrated fish farms that comprise only about a third of total shrimp farms in Indonesia. The remainder is produced by low-productive extensive and semi-intensive fish farms that generate the bulk of the employment in the sector (Dujin et al., 2012). This broad division in production systems is relevant to an analysis of supply chain standards; both manage their ponds differently, generate distinctive labor issues, and create their own environmental impacts. Hence, the ASC standard lands in different production contexts, and provokes distinctive local responses.

WWF initiated the Shrimp Aquaculture Dialogues (ShAD) in 2007, to address the sustainability challenges associated with shrimp farming. Eventually, the effort resulted in a supply chain standard for responsible shrimp production. The ASC would take care of implementation and enforcement from 2014. The ASCshrimp standard has been developed to address the environmental degradation that comes along with the expanding shrimp farming industry, and to improve the reportedly doubtful labor relations in the sector and the relations with local communities. The ASC shrimp standard targets unsustainable practices present in the shrimp industry; three issues are of specific interest for this study:

(a) Mangrove forest protection: According to the standard $10-38 \%$ of mangroves have been lost worldwide due to shrimp aquaculture, while mangroves are considered to perform critical ecosystem functions such as stabilizing soil erosion, reducing the impact of waves and storm surges, and providing habitat for many birds and marine organisms;

(b) Community relations: According to the standard, shrimp farming often has negative impacts on local communities, such as reducing public access to land and water resources and jeopardizing livelihoods;

(c) Labor conditions: According to the standard, in developing countries aquaculture often requires workers to live on or near the farm, away from their families, in a rural environment lacking good infrastructure and living conditions.

The ASC standard is part of a larger system of standards managed by the ASC. ASC was founded in 2010 by WWF and IDH (Dutch Sustainable Trade Initiative) and presents itself as "an independent not-for-profit organization with global influence" (ASC, 2014). The aquaculture standards were all developed through multi-stakeholder dialogues, organized according to the procedures of the ISEAL alliance. The standard setters agreed to use third party auditing to verify compliance with the developed standard. The ASC organization takes care of the chain of custody and ASC product label. The major technical, cultural and political characteristics of the ASC standard are summarized in Exhibit 1 and will be elaborated below.

Exhibit 1. Technical, cultural and political characteristics intrinsic to ASC

\begin{tabular}{l|l}
\hline $\begin{array}{l}\text { ASC shrimp standard } \\
\text { characteristics }\end{array}$ & Content \\
\hline Technical & $\begin{array}{l}\text { Multi-stakeholder dialogues select uniform } \\
\text { guidelines for shrimp farming practices } \\
\text { Use of third party auditing and } \\
\text { accreditation to verify compliance with the } \\
\text { developed standard } \\
\text { Centralized control of chain of custody and } \\
\text { the application of the ASC logo }\end{array}$ \\
\hline Cultural & $\begin{array}{l}\text { Create collaborative advantages and } \\
\text { consent in multi-stakeholder dialogues } \\
\text { Reliance on expert-based norms for } \\
\text { monitoring compliance with prescribed } \\
\text { good practices }\end{array}$ \\
\hline Political & $\begin{array}{l}\text { Transform global seafood markets } \\
\text { and shrimp farming by using market } \\
\text { mechanism and working towards win-win } \\
\text { situations and competitive advantages } \\
\text { Install procedures to handle tensions and } \\
\text { conflicts }\end{array}$ \\
\hline
\end{tabular}




\section{Technical characteristics}

The technical characteristics of ASC-standard are captured by the management model underlying the change processes set in motion by a standard. The ASC aims to be "the world's leading certification and labelling program for responsibly farmed seafood" and, to this end, all ASC seafood standards have three managerial features. First, the standards are developed through international multi-stakeholder Aquaculture Dialogues in which a range of stakeholders including fish farmers, processors, retailers, NGOs, government agencies and research institutes have participated. The standards are developed following the guidelines of the ISEAL Code of Good Practices for Setting Social and Environmental Standards developed by the non-governmental ISEAL Alliance (ISEAL, 2014). This code sets guidelines that standard-setting organizations can follow when developing a sustainability standard. This ISEAL code, in turn, complies with two other international standards: the ISO/IEC Guide 59 Code of Good Practice for Standardization, and the WTO Technical Barriers to Trade (TBT) Agreement Annex 3 Code of good practice for the preparation, adoption and application of standards. Second, the ASC standards use third party auditing and accreditation to verify compliance with the developed standard. In order to be certified and carry the ASC logo, the ASC standards require fish farms to hire an assessor who has been accredited by Accreditation Services International GmbH (ASI). The independence of ASC from $A S I$ and the $C A B$ has to ensure that audits are objective and certification decisions are performed without bias for all clients around the world. Third, ASC takes care of the chain of custody and ASC product label along the entire supply chain.

\section{Cultural characteristics}

The culture of the standard-setting process is visible in the preferred ways to collaborate and to correct and control. The ASCstandard relies strongly on auditing and voluntary regulation, the role of experts in defining indicators for monitoring compliance with prescribed good practices, and the reference made to consent among multiple-stakeholders. The main norms, values and beliefs underlying ASC are: expert-based criteria and multistakeholder consensus. ASC's monitoring and control norms and practices are visible in the preference for science-based and objective criteria that are usually defined by experts and believed to be globally applicable to "help protect communities and the environment, and work to ensure the ongoing viability of the aquaculture industry" (ASC, 2014). In respect of collaboration, the ASC standards are all developed through multi-stakeholder processes. The multi-stakeholder model is grounded in the belief that cross-sector partnerships are able to create legitimacy and credibility based on the collaborative advantages: the synergy resulting from the pooling of resources of dissimilar partners (Vangen \& Huxham, 2013). The ASC shrimp standard was created by the ShAD initiated by WWF-USA in 2007. This dialogue was actually preceded by a Consortium on Shrimp Farming and the Environment that started as early as 1999. This consortium consisted of WWF and mainly public sector representatives, and it identified the key negative environmental and social impacts associated with shrimp farming and developed principles to address these impacts (ASC, 2014).

\section{Political characteristics}

The political characteristics of ASC become visible in the way they frame the benefits for different stakeholder groups and in the proposed procedures to settle disputes. ASC aims to transform global seafood markets by using the market mechanism. More specifically by "connecting the farm to the marketplace by promoting responsible practices through a consumer logo" (ASC, 2014, p. 6). Using the market logic means that there have to be competitive advantages associated with using the ASC standards. ASC attempts to involve different stakeholders in aquaculture value chains (fish farmers, processors, traders, distributors, retailers, food service companies, and consumers) and claims it offers different benefits for each group. Overall market value can be enhanced through greater credibility within the industry and among consumers, while adopting best practices promotes competitive advantage as an industry front-runner (ASC website, 2014). Intensive farm owners are promised a stronger position in existing markets and opportunities to tap into new ones. Smallholders can benefit from collectively sharing certification and costs, and processers are attracted by the argument that the fish and shrimp that they procure is "farmed with the utmost care for people and the environment" and traced back through the supply chain (ASC, 2014). Finally, consumers can buy fish in the knowledge that the ASC logo ensures responsible production methods (ASC, 2014). Through outreach and marketing, the demand for ASC labelled products can be created and expanded (ASC, 2014). Governments can benefit because the standard conforms to the Millennium Development Goals, while the standard is supposed to be a major support for social and environmental NGOs because of its effective approach through markets. A formal objections procedure has been developed for those stakeholders who may feel disadvantaged by the ASC certification process (ASC, 2014). 


\section{Local responses to the global standard: Degrees of fit}

\section{Technical fit}

While ASC has the specific aim to be the leading standard in aquaculture and in shrimp, it was developed among a plethora of partly overlapping standards present in the organizational field. These standards are from the public and/or private sphere and are either nationally or internationally oriented. The main public Indonesian aquaculture standard is the CBIB (sometimes referred to as IndoGAP), developed by the Directorate General of Fisheries and Aquaculture "to meet the demands and requirements of shrimp quality in the international market". CBIB stands for Cara Budidaya Ikan yang Baik - in English: Good Aquaculture Practice (GAP) - and it sets criteria for how to produce shrimp in terms of food safety and how to reduce the impact on the environment. The government tries to socialize GAP among shrimp farmers so that they produce safer products, with lower environmental impact (interview 2-2). The government standard is primarily technical (feeding efficiency, reduction of waste water, etc.) and social issues are not covered (interview 2-2). However, the CBIB standard is currently being revised to also include social and environmental issues (interview 3-2). Indonesian NGOs, such as Telapak, and Wetlands International Indonesia were invited by the government to provide input (interview 1-2, 16-2). While CBIB is currently voluntary, it is expected to become mandatory in the future (interview 3-2, 4-2). All products, including shrimp, also need to comply with the Indonesian National Standard for Industrial Production to sell in the domestic market (interview 2-2). Other important public standards include the mandatory public (safety) standards from the various importing countries (Europe, USA, Japan, and China) (interview 2-2). Another private aquaculture standard present in the organizational field is the standard developed by the Global Aquaculture Alliance (GAA) in the USA. "The GAA Best Aquaculture Practices standard (also referred to as ACC) is a certification system that combines site inspections and effluent sampling with sanitary controls, therapeutic controls and traceability" (Aquaculture Certification Council, 2014). While ASC is still very new, the GAA standard for the US market is a more established standard for shrimp production in Indonesia (interview 16-2).

Most interviewees agree that the current number of standards in the industry is confusing, (interview 4-2, 6-2, 7-2). A processor complains about having to deal with too many standards, while he cannot assign an employee or department especially to this issue (interview 6-2). However, the existence of multiple, related standards does not necessarily threaten ASC; rather it might enhance the technical fit of the ASC standard with the organizational field. One interviewee (10-2) mentioned that principle 4 of the ASC shrimp standard (on labor) is almost the same as the principles in the GAA standard and GlobalGAP. Therefore, there are no problems expected in implementing this principle (interview 10-2, 13-2). Many of the other aquaculture standards (ACC, GlobalGAP, Naturland) also address the protection of mangroves (interview 10-2, 12-2, 16-2). The overlap of related standards tends to reduce the institutional gaps between the ASC shrimp standard and the organizational field. For example, one of the visited shrimp farms (13-2) already cooperates with a local NGO with regard to mangrove rehabilitation. This shrimp farm acknowledges that mangroves are important: the trees clean the water from toxics brought in by sea water, and buyers increasingly stress the need for mangrove rehabilitation. Moreover, the GAA standard requires protective measures concerning mangroves (interview 13-2). According to another interviewee (7-2) the business association Shrimp Club Indonesia (SCI) was formerly not interested in any kind of certification. They said: "we will just sell to the domestic market, because they don't have these complicated demands". However, $\mathrm{SCl}$ is now involved with GlobalGAP and GAA (interview 9-2).

The intertwinement of standards is enhanced by the so-called institutional spill-over effects. Our data show signs of a network of standards, rather than just competing arrangements. AseanGAP is a new aquaculture standard for East Asian member countries of ASEAN, and the person behind this standard was formerly involved in the ASC shrimp standard (interview 5-2). CBIB was also said to be related to AseanGAP (interview 1-2). The standards are therefore very similar (interview 5-2). Furthermore, the Indonesian branch of WWF (WWF-ID) was involved in ASC, but now collaborates with the government on a new CBIB standard, which addresses not only food safety issues but also environmental and social aspects (interview 5-2). Another interviewee (18-2) stressed ASC's influence on related standards. Today, the new GAA standard very much resembles the ASC standard (interview 18-2). "In a press release [....] GlobalGAP announced that they will harmonize the standard when the final ASC standard is published. These standards are competitors of ASC, but at the same time are influenced by it" (interview 18-2). This network of standards seems to be largely industry-bound. None of our interviewees saw links with well-known sustainability standards developed in another important Indonesian industry, like the Roundtable on Sustainable Palmoil (RSPO) and the Indonesian Sustainable Palm Oil (ISPO), even though many NGOs operate in both sectors.

The second dimension of technical fit refers to the degree of technological advancement in the organizational field. As 
indicated above, shrimp farming systems in Indonesia are highly diversified. "The problem is to implement the standard. There are farms with different scales, which have different problems" (interview 5-2). Many interviewees see ASC certification as only fit for intensive shrimp farming (interview 4-1, 14-1, 1-2, 6-2, 11-2, $15-2,16-2,18-2)$. "ASC is written from the perspective of big companies with surrounding communities. However, individual farmers are part of the community. They are dealing with their neighbors. I don't think ASC will change these issues, because ASC as a standard needs to have a standard that applies to all farmers" (interview 1-2). "For smallholders it will be hard to get ASC certification, especially because of the mangrove, because big companies are more aware of the benefits of the mangrove than smallholders" (interview 11-2). However, interviewees increasingly see people value the mangroves and their rehabilitation (interview 11-2, 15-2). The legality of shrimp farms is a problem; it is difficult to determine exactly the original boundaries of mangrove forests. Documents are often conflicting (interview 10-2), or not accessible. One interviewee brought some smallholder farmers to an ASC shrimp meeting in Jakarta, but the English language of the ASC standard prevented their full participation in the discussions (interview 18-2).

The costs of certification are considered the main hindrance to smallholder participation in ASC certified supply chains (interview 4-1, 14-1, 4-2, 10-2). "Farmers will ask why they should pay because they do not see the benefits of certification; they do not get anything in return for their investment. Moreover, we doubt farmers can afford the payment" (Interview 14-1). "ASC private certification is very expensive" (interview 4-2). "Farmers prefer CBIB certification, because certification under CBIB is free" (interview 10-2). CBIB also has problems reaching all farmers, especially smallholders (interview 4-2, 6-2, 15-2). However, none of the other private standards seem to be small-scale farming oriented either. Nonetheless, ASC wants to become more inclusive and tries to accommodate group certification to enable groups of small to medium sized farms to work collectively towards compliance and collective certification with the ASC shrimp standard (ASC, 2016). The group certification project was initiated back in 2013, but was put on hold and is scheduled to be completed in 2016 (ASC, 2016). CBIB also considers adopting group certification (interview 16-2).

\section{Cultural fit}

While the development of ASC standards is organized as a multistakeholder process, many of the interviewed stakeholders were not part of this process and do not perceive it as such.
Our interviews revealed that European NGOs and private sector representatives, as well as Indonesian NGOs, had actively participated in the multi-stakeholder dialogues, whereas the Indonesian private sector had not. One interviewee asked: "Will every EU country come up with its own standard? The Netherlands now has ASC, Great Britain has the BRC (British Retail Consortium), and we have heard the French will come with LCA [life cycle assessment]" (interview 4-2). Many interviewees perceive ASC as a European aquaculture standard, the counterpart of the American ACC, and not a global private arrangement. Moreover, the large majority of our interviewees had never heard of ASC before. The prime exception is a consortium of Indonesian NGOs, including WWF-Indonesia, Telapak and Wetlands Indonesia. These environmental and social NGOs maintain close relationships with international NGOs, and they have provided supportive input to the ASC standard indirectly, via their international ties (interview 18-2).

Nonetheless, several norms and practices incorporated in the ASC have already been established in the organizational field because of other, related standards. One example is the practice of cross-sectoral collaboration. The Sustainable Fisheries Partnership (SFP) also encourages producer associations, such as the $\mathrm{SCl}$, to implement a zonal management approach to ensure collaborative management to reduce disease risks (interview 9-2, 10-2). To attain their goals the associations work together with different government agencies. Furthermore, SFP is involved in organizing Aquaculture Policy Roundtables to address sustainability issues. These roundtables attract business associations such as $\mathrm{SCl}$ and $\mathrm{AP}_{5} \mathrm{I}$, but also scientists, NGOs and governmental agencies. All these stakeholders are Indonesian (interview 10-2).

The cultural fit of ASC's social standards in the Indonesian context is more difficult. "The social standards are not applicable in Indonesia, since they do not fit the culture. The standard requires a written contract between people; however, if you write something down in Indonesia, it means you don't trust the person. Therefore, the standards should differentiate between different cultures" (interview 1-2). "A Participatory Social Impact Assessment (P-SIA) will work, but not in the way intended by ASC. They will expect written documents that can be made public. Telapak has prepared 2 documents now, but I don't think they will make any significant change in the village regarding the acceptance of ASC or any other certification demanded by international market. It may be better to connect the P-SIA to the spiritual events organized every week: Koran reading or Friday prayer" (interview 1-2).

The ASC shrimp standard incorporates SA8000, a global social accountability standard for working conditions, developed 
and overseen by Social Accountability International (SAI). This standard addresses, among other things, child and forced labor, discrimination, corporate discipline (and punishment), freedom and right to collective bargaining. Interviewees expressed doubts as to what extent adoption of these norms is relevant and auditable. SA800o fits companies, not necessarily traditionbased fish farm systems. "Shrimp ponds aren't shoe factories" (Interview 3-1). Moreover, implementing the ASC standard requires a formal contract between producers and buyers and a necessity to meet, e.g., traceability requirements. This can create frictions in rural areas where labor relations between pond owners and workers are usually family-related. They work on the basis of informal and trust-based contracts. The introduction of written contracts would be considered as a sign of distrust (interview 5-1).

\section{Political fit}

The market logic underlying ASC seems to fall short in the Indonesian shrimp industry. This market logic assumes demanddriven chains in which lead firms can set the demands under which the rest of the value chain operates. While shrimp is an important product for Indonesia in terms of export, the domestic demand for the product is also high. Our data suggest that the value chain is rather a supply driven chain. Indonesian processors are currently well under their processing capacity and would like to buy much more shrimp (interview 6-2). "Currently, the bargaining power is with the farmers. Processors will buy any shrimp, because supply is too low. In this respect, Indonesia is very different from other major exporters, like Thailand that suffer from EMS (early mortality syndrome in shrimp). "Currently the domestic market gives a competitive price” (interview 10-2). "Farmers can easily sell; the price of shrimp is already very good and makes people rich at the moment" (interview 1-2). "Farmers cannot imagine that they will ever have a problem to sell their shrimp. These farmers have little education and they don't see a need for certification" (interview 1-2). "Big farmers are selling directly to processors. They choose their outlet depending on how fast they can get paid and whoever gives the highest price. There are no contractual regulations for the selling of the raw material. Farmers can choose who to sell to. Everybody (domestic, regional and international) wants to buy shrimp; no matter what the quality is" (interview 1-2).

Because of the high demand and high price for uncertified shrimp in the period of the interviews (2011-2014), there seemed to be very little incentive among producers to engage in a certification scheme. "Farmers are reluctant to adopt the ASC scheme, because there is no incentive; they can sell their products anyway" (interview 4-2). "Overall $\mathrm{SCl}$ is okay with the
ASC, or whatever certification system. But there should be a benefit for the farmer. Why should he invest when there is no pay-off? With regard to ASC we have the policy of wait and see. Farmers will follow a standard when it improves production or productivity for them. This is what $\mathrm{SCl}$ stresses when they train farmers in new systems" (interview 9-2). Not only ASC faces this problem, but others - whether public or private systems - face this issue as well. In order to implement CBIB, the provincial government in East Java contacts the processors, finds out which suppliers they have, and then goes to these farms to introduce the CBIB and certify them. If they go directly to farmers, there is no incentive for farmers to get certified. The processor requires them to cooperate with the CBIB (interview 8-2). Except for the free program, the provincial government in Lampung does not create other incentives for the adoption of the CBIB standard. "However, the standard is now being required by a few buyers as a minimum standard. There is no price difference between CBIBcertified and non-certified shrimp. Both have their own market" (interview 15-2).

"The government is OK with ASC or similar "private certification" standards as long as they are in line with the CBIB" (interview 5-2). "The authorities have realized that standards are part of the trade world, and they therefore used them to make the sector more competitive" (interview 2-2). The government has many programs related to certification. However, "it is very difficult for the government to implement all these programs because the country is so big and there are so many different companies, and because they lack the budget to do this" (interview 6-2, 15-2). Besides certification programs, Indonesia has rules and regulations to protect the mangrove in the so-called 'greenbelt', which is a belt of 50-100 meters of mangrove forests along the coast that must be maintained. In theory, the existence of this regulation would provide a good political fit with the ASC standard. However, the implementation of the law is not successful due to a lack of enforcement: "Government monitoring and implementing of the rehabilitation projects are not effective yet. There are not sufficient professionals in the field (interview 2-2). "Government officials say there is no real punishment for violating mangrove regulation. When pond owners develop a new fish pond in the green belt area, the responsible authorities write to them by way of punishment and assume this prevents pond owners from doing it again" (interview 15-2). The prevalence of corruption is also not helpful: "Bupaties [heads of rural districts] give out permits in exchange for votes and other political reasons; 'Money talks' " (interview 17-2).

Another difficulty in implementing regulation is that the relevant ministries seem to hinder each other. "Mangrove is considered a forest and is still under the Ministry of Forestry and 
not under the Ministry of Fisheries and Marine Affairs. There is a long-time dispute between the two ministries. This is mostly related to competition over money" (interview 1-2). The difficulties between the different ministries are also acknowledged by a representative of the Ministry of Forestry (interview 17-2). However, many NGOs and universities are promoting mangrove restoration and protection. In this respect, the ASC norms on mangrove forest could potentially fit very well with a specific part of the organizational field.

The influence of NGOs on government policy changed tremendously in Indonesia after the democratization of 1998. A government official commented: “NGOs check our policies and activities on aquaculture development. After the democratization era, NGOs became very strong and powerful to control government policy implementation. Because they are close to journalists they influence the media and reach millions of people with their campaigns" (interview 4-2). NGOs also cooperate with the Ministry of Marine Affairs and Fisheries, especially DG Aquaculture (interview 4-2), which is confirmed by NGOs (interview 1-2). The Indonesian NGO Telapak, for example, changed its strategy from only investigating, protesting and campaigning against the government towards helping to find a solution as well. This improved the relation with the Ministry. Telapak trains farmers to diversify their production, for example (interview 1-2). Nevertheless, government-NGO cooperation remains sensitive. Another government official denies that his department cooperates with NGOs (LSMs): “NGOs don't have a good name in Indonesia. Many NGOs are just established to ask money from the government. If they help the people it is OK. NGOs work with authorities, but only at the district level" (interview 8-2).

\section{Exhibit 2. Degrees of fit}

\begin{tabular}{l|l|l}
\hline Type of fit & Content & Degree of fit \\
\hline Technical & Presence of multitude of standards & Medium - High \\
& $\begin{array}{l}\text { Technical diversity of production } \\
\text { Cultural }\end{array}$ & Low \\
\hline Political & $\begin{array}{l}\text { Expert-based criteria } \\
\text { for different stakeholder groups }\end{array}$ & Low \\
\hline \multirow{2}{*}{$\begin{array}{l}\text { Public rules and regulations } \\
\text { present in organizational field }\end{array}$} & Low \\
\hline
\end{tabular}

\section{Emergent signals of fitting}

Exhibit 2 summarizes our findings in terms of degrees of technical, cultural and political fit. Although the degrees of fit are quite low, we still found indications of processes of fitting embedded in on-going endeavors to conserve mangrove forests, to work with local communities and to address labor conditions in the Indonesian shrimp sector. Our research findings indicate that local NGOs, including local branches of international NGOs, play the most important mediating role in shaping processes that lead to fitting. This is not surprising because the sustainability standards are often supportive to NGOs' agendas. Due to their local embeddedness, the local NGOs tend to be instrumental in the process of fitting, which can both entail an alteration of the standard or alterations in the organizational field to create a better fit between the two. The capacity of NGOs to mediate greatly benefits from the presence of their staff in professional networks in the Indonesian fisheries and marine sector, which act quite independently from ongoing political processes.

First, we found signs of technical fittin'. NGOs mediated between the ASC standard and smallholder farmers by preparing smallholders for ASC certification and by adapting the standard. Telapak introduced some practices called 'responsible shrimp farming' among smallholders which were taken from the ASC shrimp standard principles 3 and 4 (interview 1-2). These principles mainly concern considerations for surrounding communities and labor issues. Moreover, NGOs mediate between the ASC standard and existing public standards in the Indonesian shrimp sector. As mentioned, WWF-Indonesia (which is involved in ASC) collaborates with the government on a new version of the public CBIB standard, which will not only include food safety issues but also environmental and social aspects (interview 5-2). NGOs also act as mediators between the ASC standard and other private standards present in the organizational field. The constructed technical fit within the portfolio of standards seems to reflect a normative convergence within the network of standards on farmed shrimp.

Second, we found signs of cultural fitting. ASC requires bookkeeping and formalization of relations with collectors and employees. NGOs and extension agencies believe they can help farmers learn to modernize in this respect, in spite of it being at odds with the local culture (Interview 3-1, 1-1, 7-1). The question however is whether farmers have the intention to learn about rules that they regard as contrary to their own interests. Contracts increase traceability and visibility of farm activities also for tax agencies. Bookkeeping and formalization "scares farmers off because they may face an additional (value added) tax burden on top of the land use tax they already currently pay" (Interview 13-1). 
Third, we found signs of political fitting. Telapak, an Indonesian NGO, tried to develop social institutions to strengthen communities' capacities to increase their welfare. This, Telapak thinks, will help them to be better prepared for future certification (interview 1-2). Telapak aims to ensure incentives for smallholder farmers and is involved, for example, in working with communities of farmers to generate income from mangrove products like syrups (interview 1-2). SFP engaged in a similar process of fitting. They saw that farmers were not keen on engaging in ASC certification. "To ensure incentives for farmers, SFP asked SCI to provide smallholder farmers with training that teach them to be more responsible/sustainable and, at the same time, increase their production; in return, $\mathrm{SCl}$ members will receive benefits such as a safer and better environment" (interview 10-2). Moreover, the NGO SNV (Dutch Development Organization) opened an office to help farmers implement ASC with joint funding from the Dutch Government. However, it is often difficult to help farmers prepare for certification. SNV provided seedlings to farmers, which they just threw away. They were used to get help in the form of money after the tsunami, therefore, they didn't appreciate help in kind (interview 18-2).

\section{CONCLUSIONS}

This paper used the concept of institutional fit to assess the transformative capacity of a private, voluntary and global sustainability standard in the Indonesian shrimp industry. Our analysis makes the transformative capacity of sustainability standards dependent on how the institutional DNA of the standard itself, i.e. the configuration of technical, cultural and political characteristics, fits a given localized organizational field. The degree of fit between the ASC and the changeful, complex reality in the Indonesian shrimp sector, mangrove forests and local communities appears to be low. This may induce a decoupling of the sustainability plans underlying the foreign standard and the varied shrimp farming practices and collective endeavors to address sustainability issues, in particular the protection of mangrove forests. The institutions defined at the level of the global partnership translate into rules that are appropriate for and renegotiated by firms, NGOs and retailers acting at a global level, but the diffusion into embedded private and public networks remains low. Moreover, feedback and co-creation rooted in local practices and collaborations have little impact on the nature of the institutions accompanying the global sustainability standard. However, the paper also signaled subtle processes of fitting, which were mainly mediated by NGOs. This shows that local NGOs, often vertically linked to salient international NGOs acting at a global level, can play important mediating roles between a global standard and a local organizational field. The question remains whether a global standard is flexible enough to align with the variety of local projects assembling a diversity of private, civic and public actors aiming at conservation of mangrove forests. Although the initial focus of the ASC standard is on large-scale and intensive shrimp farming, its transformative capacity in Indonesia largely depends on its acceptance by and connection with locally constructed rules and practices directing sustainable change in the context of threatened mangrove forests. This suggests that global sustainability standards can benefit from steering more explicitly on dovetailing regulative and normative structures of global and local organizational fields.

The paper contributes to the growing literature on global value chains and sustainability standards that recognizes the importance of the responses of locally embedded networks and social groups. It relates the transformative capacity of global standards to the often stubborn and uncertain process of diffusion into local organizational fields. In contrast to assessments focusing exclusively on the ultimate outcomes generated by global sustainability standards, the institutional lens used in this paper suggests to concentrate on intermediate processes shaping the potential of a global standard to enhance or catalyze locally embedded sustainability initiatives. This allows unpacking the processes that explain whether a sustainability standard only connects to specific conditions and suppliers, is decoupled from local practices and sustainability initiatives or accommodates a certain level of flexibility to create an institutional fit with on-going sustainability efforts in a specific production environment.

\section{ACKNOWLEDGEMENTS}

This article was written as part of the value chain track of the Partnerships Resource Centre. We would like to thank Dikky Indrawan for his invaluable contributions as our research assistant in Indonesia. Furthermore, we would like to thank our interviewees for their cooperation, and two anonymous reviewers for their sharp comments, which helped us strengthen our argument. We dedicate this paper to Marieke Douma, whose enthusiasm for doing fieldwork was an essential contribution.

\section{REFERENCES}

Aquaculture Certification Council. (2014). Best aquaculture practices certification: The responsible seafood choice. Retrieved from http:// www.aquaculturecertification.org/ 
Adolf, S., Bush, S. R., \& Vellema, S. (in press). Reinserting state agency in global value chains: The case of MSC certified skipjack tuna. Fisheries Research. Retrieved from http://ac.els-cdn.com/ So165783615301430/1-S2.0-S0165783615301430-main.pdf? tid=dbea02 $\mathrm{b} 8-20 \mathrm{e} 4-11 \mathrm{e} 6-8 \mathrm{~b} 52-00000 \mathrm{abof} 6 \mathrm{c} \&$ acdnat $=146400797$ 9_97590314d5a3of54f91dco778ba5f885

Anderson, J. (2015, October 26-29). Annual survey on world farmed shrimp production. Paper presented at the Global Outlook on Aquaculture Leadership (GOAL) Conference, Global Aquaculture Alliance, Vancouver, British Columbia, Canada.

Ansari, S. M., Fiss, P. C., \& Zajac, E. J. (2010). Made to fit: How practices vary as they diffuse. Academy of Management Review, 35(1), 67-92.

Aquaculture Stewardship Council. (2014). About the ASC. Retrieved from http://www.asc-aqua.org/index.cfm?act=tekst.item\&iid=2\&l$n g=1$

Aquaculture Stewardship Council. (2014, March). ASC Shrimp Standard Version 1.o, Utrecht, The Netherlands.

Aquaculture Stewardship Council. (2016). Terms of reference (ToR) for development of ASC group certification methodology. Retrieved from http://www.asc-aqua.org/upload/ToR_Group\%2ocertification\%20 project_v.1.11.pdf

Bartley, T. (2010). Transnational private regulation in practice: The limits of forest and labor standards certification in Indonesia. Business and Politics, 12(3), 1469-3569. doi:10.2202/1469-3569.1321.

Bitzer, V., Francken, M., \& Glasbergen, P. (2008). Intersectoral partnerships for a sustainable coffee chain: Really addressing sustainability or just picking (coffee) cherries? Global Environmental Change, 18(2), 271-284. doi:10.1016/j.gloenvcha.2008.01.002

Boström, M., Jönsson, A. M., Lockie, S., Mol, A. P. J., \& Oosterveer, P. (2015). Sustainable and responsible supply chain governance: Challenges and opportunities. Journal of Cleaner Production, 107(16), 1-7. doi:10.1016/j.jclepro.2014.11.050

Boxenbaum, E., \& Pederson, J. S. (2009). Scandinavian institutionalism - a case of institutional work. In T. B. Lawrence, R. Suddaby, B. Leca (Eds.), Institutional work: Actors and Agency in Institutional Studies of Organizations (pp. 178-204). Cambridge, UK: Cambridge University Press.

Bromley, P., Hwang, H., \& Powell, W. W. (2012). Decoupling revisited: Common pressures, divergent strategies in the US nonprofit sector. M@n@gement, 15, 469-501. doi: 10.3917/mana.155.0469

Bromley, P., \& Powell, W. W. (2012). From smoke and mirrors to walking the talk: Decoupling in the contemporary world. The Academy of Management Annals, 6(1), 483-530. doi:10.1080/19416520.2012.68 4462

Bush, S., \& Oosterveer, P. (2015). Vertically differentiating environmental standards: The case of the Marine Stewardship Council. Sustainability, 7(2), 1861-1883. doi:10.3390/su7021861

Bush, S. R., Oosterveer, P., \& Bailey, M, \& Mol, A. P. J. (2015). Sustainability governance of chains and networks: A review and future outlook. Journal of Cleaner Production, 107(16), 8-19. doi:10.1016/j.jclepro.2014.10.019

Djama, M., Fouilleux, E., \& Vagneron, I. (2011). Standard-setting, certifying and benchmarking: A governmentality approach to sustainability standards in the agro-food sector. In S. Ponte, P. Gibbon, \& J. Vestergaard (Eds.), Governing through standards: Origins, drivers and limitations (pp. 184-209). Basingstoke, UK: Palgrave MacMillan.
Duijn, A. Van, Beukers, R., \& Pijl, W. Van Der. (2012). The Indonesian seafood sector: $A$ value chain analysis. CBI Report, CBI and LEI Wageningen University, Wageningen, The Netherlands.

Foley, P. (2013). National government responses to Marine Stewardship Council (MSC) fisheries certification: Insights from Atlantic Canada. New Political Economy, 18(2), 284-307. doi:10.1080/13563467.2012 684212

Foley, P., \& Havice, E. (2016). The rise of territorial eco-certifications: New politics of transnational sustainability governance in the fishery sector. Geoforum, 69, 24-33. doi:10.1016/j.geoforum.2015.11.015

Foley, P., \& Hébert, K. (2013). Alternative regimes of transnational environmental certification: Governance, marketization, and place in Alaska's salmon fisheries. Environment and Planning A, 45(11), 27342751. doi:10.1068/a45202

Foley, P., \& McCay, B. (2014). Certifying the commons: Eco-certification, privatization, and collective action. Ecology and Society, 19(2), 28. doi:10.5751/ES-06459-190228

Gereffi, G. (2013). Global value chains in a post-Washington Consensus world. Review of International Political Economy, 21(1), 9-37. doi:10.1 080/09692290.2012.756414.

Glasbergen, P., \& Schouten, G. (2015). Transformative capacities of global private sustainability standards: A reflection on scenarios in the field of agricultural commodities. Journal of Corporate Citizenship, 2015(58), 85-101. doi:10.9774/gleaf.4700.2015.ju.00010

Havice, E., \& Iles, A. (2015). Shaping the aquaculture sustainability assemblage: Revealing the rule-making behind the rules. Geoforum, 58 , 27-37. doi:10.1016/j.geoforum.2014.10.008

Helmsing, A. H. J., \& Vellema, S. (2011). Governance, inclusion and embedding. Value chains, social inclusion and economic development: Contrasting theories and realities. London, UK: Routledge.

International Social and Environmental Accreditation and Labelling. (2014). Setting Social and Environmental Standards ISEAL Code of Good Practice: Version 6.o. Retrieved from https://www.isealalliance.org/sites/default/files/ISEAL\%20Standard\%20Setting\%20 Code\%20v6\%20Dec\%202014.pdf

Kusumawati, R., Bush, S. R., \& Visser, L. E. (2013). Can patrons be bypassed? Frictions between local and global regulatory networks over shrimp aquaculture in East Kalimantan. Society and Natural Resources, 26(8), 898-911.

Lawrence, T. B., Hardy, C., \& Phillips, N. (2002). Institutional effects of interorganizational collaboration: The emergence of proto-institutions. Academy of Management Journal, 45(1), 281-290.

Manning, S., Boons, F., \& Hagen, O. Von, \& Reinecke, J. (2012). National contexts matter: The co-evolution of sustainability standards in global value chains. Ecological Economics, 83, 197-209. doi:10.1016/j. ecolecon.2011.08.029

Marti, I., \& Mair, J. (2009). Bringing change into the lives of the poor: Entrepreneurship outside traditional boundaries. In T. B. Lawrence, R. Suddaby, \& B. Leca (Eds.), Institutional work: Actors and agency in institutional studies of organizations (pp. 92-119). Cambridge, UK: Cambridge University Press.

Marx A., Maertens M., Swinnen J., \& Wouters J (2012). Conclusion: Private standards - a global governance tool? In A. Marx, M. Maertens, J. Swinnen, \& J. Wouters (Eds.), Private Standards and Global Governance: Economic, legal and political perspectives (pp. 293-309), Cheltenham, Edward Elgar. 
McCarthy, J. F., Gillespie, P., \& Zen, Z. (2012). Swimming upstream: Local Indonesian production networks in "globalized" palm oil production. World Development, 40(3), 555-569. doi:10.1016/j.worlddev.2011.07.012

Otieno G., \& Knorringa P. (2012). Localizing Global Standards: Illustrative examples from Kenya's horticulture sector. In M. P. v. Dijk \& J. Trienekens (Eds.), Global Value Chains: Linking local producers from developing countries to international market (pp. 119-135), Amsterdam, Amsterdam University Press,.

Ponte, S. (2008). Greener than thou: The political economy of fish ecolabeling and its local manifestation in South Africa. World Development, 36(1), 159-175. doi:10.1016/j.worlddev.2007.02.014

Ponte, S., \& Cheyns, E. (2013). Voluntary standards, expert knowledge and the governance of sustainability networks. Global Networks, 13(4), 459-477. doi:10.1111/glob.12011

Ponte, S., Gibbon, P., \& Vestergaard, J. (2011). Conclusion: The current status, limits and future of 'governing through standards'. In S. Ponte, P. Gibbon, \& J. Vestergaard (Eds.), Governing through standards: Origins, drivers and limitations (pp. 289-304). Basingstoke, UK: Palgrave MacMillan.

Rivera-Santos, M., Rufin, C., \& Kolk, A. (2012). Bridging the institutional divide: Partnerships in subsistence markets. Journal of Business Research, 65(12), 1721-1727. doi:10.1016/j.jbusres.2012.02.013

Schouten, G., \& Bitzer, V. (2015). The emergence of Southern standards in agricultural value chains: A new trend in sustainability governance? Ecological Economics, 120, 175-184. doi:10.1016/j.ecolecon.2015.10.017

Schouten, G., Vellema, S., \& Wijk, J. Van. (2014). Multinational enterprises and sustainability standards: Using a partnering-intensity continuum to classify their interactions. In R. van Tulder, A. Verbeke, \& R. Strange (Eds.), International Business and Sustainable Development (Progress in International Business Research) (pp. 117-139). Bingley, UK: Emerald Group Publishing Limited.
Shrimp Aquaculture Dialogue. (2008, January). Shrimp Aquaculture dialogue standards development for responsible shrimp farming, Madagascar. Retrieved from http://assets.worldwildlife. org/publications/265/files/original/Shrimp_Aquaculture_Dialogue_\%E2\%80\%93_Standards_Development_for_Responsible_ Shrimp_Farming_Madagascar_ShrimpXX.pdf?1344881931

Shrimp Aquaculture Dialogue. (2010, October 15). Shrimp aquaculture dialogue process document, final version. Retrieved from http://assets.worldwildlife.org/publications/258/files/original/ Shrimp_Aquaculture_Dialogue_\%E2\%80\%93_Process_Document_ ShrimpYY.pdf?1344881316

Ton, G., Vellema, S., \& Ge, L. (2014). The triviality of measuring ultimate outcomes: Acknowledging the span of direct influence. IDS Bulletin, 45(6), 37-48. doi:10.1111/1759-5436.12111

Vangen, S., \& Huxham, C. (2013). Building and using the theory of collaborative advantage. In R. Keast, M. Mandell, \& R. Agranoff (Eds.), Network theory in the public sector: Building new theoretical frameworks. New York, USA: Taylor and Francis.

Vellema, S., Ton, G., Roo, N. de, \& Wijk, J. Van. (2013). Value chains, partnerships and development: Using case studies to refine programme theories. Evaluation, 19(3), 304-320. doi:10.1177/1356389013493841

Vellema, S., \& Wijk, J. Van. (2015). Partnerships intervening in global food chains: The emergence of co-creation in standard-setting and certification. Journal of Cleaner Production, 107, 105-113. doi:10.1016/j.jclepro.2014.03.090

Wijen, F. (2014). Means versus ends in opaque institutional fields: Trading off compliance and achievement in sustainability standard adoption. Academy of Management Review, 39(3), 302-323. doi:10.5465/ amr.2012.0218

Zietsma, C., \& McKnight, B. (2009). Building the iron cage: Institutional creation work in the context of competing protoinstitutions. In T. Lawrence, $\mathrm{R}$. Suddaby, \& B. Leca (Eds.), Institutional work: Actors and agency in institutional studies of organizations (pp. 143-177). Cambridge, UK: Cambridge University Press. 